\title{
TINJAUAN PENERAPAN PUNGUTAN PAJAK DAN ZAKAT MENURUT KONSEP EKONOMI ISLAM DI INDONESIA
}

\author{
Nurul Ichsan \\ Universitas Islam Negeri Syarif Hidayatullah Jakarta, Email : $\underline{\text { nurul.ichsan@ @injkt.ac.id }}$
}

\begin{abstract}
ABSTRAK
Tulisan ini bertujuan untuk menganalisis suatu masalah yang kontroversial pada saat ini terutama berkenaan dengan pengambilan harta sebagai sumber pendapatan negara yang dalam era modern lebih dikenal dengan istilah pajak yang diperoleh dari harta masyarakat untuk keperluan suatu negara yang pada hakekatnya harus dikembalikan bagi kemakmuran masyarakat yang ditinjau dari perspektif Ekonomi Islam. Pungutan harta rakyat dalam Islam yang diajarkan oleh Rasulullah SAW sebagai pemimpin tentunya berbeda tujuan, cara, ketentuan dan jenisnya dengan yang ada pada negeri negeri muslim saat ini, khususnya Indonesia. Metode kualitatif yang digunakan dalam kajian ini bertujuan untuk mengetahui, mengeksplorasi dan menjelaskan bagaimanakah pandangan Ekonomi Islam mengenai pungutan harta yang ada pada era modern ini dengan metode pengumpulan data kepustakaan (library research). Hasil dari kajian menunjukan bahwa sinergitas antara pajak dan zakat di Indonesia hanya sebatas ada dalam sebahagian regulasi perundang undangan tetapi belum ada skema lain yang aplikatif, misalnya ada kolaborasi antara BAZNAS sebagai badan resmi amil zakat tingkat nasional dan pemerintah melalui direktorat perpajakan. Kolaborasi dalam program program seperti penyuluhan, promosi, informasi di media serta dalam meningkatkan target penerimaan zakat dan pajak sehingga manfaat peningkatan penerimaan zakat dan pajak tersebut dapat maksimal serta berdampak positif bagi program pengentasan kemiskinan di Indonesia.
\end{abstract}

Kata-Kata Kunci : Pajak, Zakat, Kharaj, Dharibah, Usyr, Maks

\begin{abstract}
This paper aims to analyze a controversial problem at this time, especially with regard to the taking of property as a source of state income which in the modern era is better known as the tax obtained from the public property for the needs of a country that essentially must be returned to the prosperity of the community which is viewed from perspective of Islamic Economics. The collection of public property in Islam which was taught by the Muhammad SAW as a leader certainly differed in purpose, manner, conditions and type with those in the Muslim country today, especially Indonesia. The qualitative method used in this study aims to find out, explore and explain how the views of the Islamic Economy regarding property levies that exist in this modern era with library data collection methods (library research). The results of the study show that the synergy between tax and zakat in Indonesia is only limited to part of the legislation but there are no other applicable schemes, for example there is collaboration between BAZNAS as the official body of amil national zakat and governmental through the taxation directorate. Collaboration in program programs such as counseling, promotion, information in the media and in increasing the target of zakat and tax revenues so that the benefits of increasing zakat and tax revenues can be maximized and have a positive impact on poverty alleviation programs in Indonesia.
\end{abstract}

Keywords : tax, Kharaj, Dharibah, Usyr, Maks 


\section{Islãmadîna \\ JURNAL PEMIKIRAN ISLAM}

Volume 19, No. 2, September $2018: 75-91$

\section{PENDAHULUAN}

Manusia mengemban amanah sebagai khalifah di muka bumi untuk mencari nafkah dengan cara halal, serta menghindari cara zulm dan batil. Islam mengakui kepemilikan pribadi dan tidak membatasinya, tetapi melarang perolehan kekayaan dengan cara-cara ilegal dan amoral. Namun demikian, dalam harta pribadi tetap tersimpan hak orang lain dalam bentuk zakat, infaq, dan sadaqah berdasarkan pendekatan syariah, sedangkan pajak berdasarkan pendekatan hukum positif yang berlaku di Indonesia.

Kebijakan fiskal merupakan kebijakan yang memengaruhi Anggaran Pendapatan dan Belanja Negara (APBN). Kebijakan fiskal diartikan sebagai langkah pemerintah untuk membuat perubahan-perubahan dalam sistem pajak. Status harta hasil pengumpulan itu adalah milik negara dan bukan milik individu. Meskipun demikian, dalam batas-batas tertentu, pemimpin negara dan para para pejabat lainnya dapat menggunakan harta tersebut untuk mencukupi kebutuhan pribadinya.

Tempat pengumpulan itu dalam ensiklopedi ekonomi Islam disebut sebagai baitul mal (rumah harta) atau bendahara negara. Apapun yang ingin dibuat oleh pemerintah Indonesia yang berkenaan dengan baitul mal atau harta masyarakat muslim tentunya juga harus mempertimbangkan ajaran Islam yang wajib dilaksanakan oleh kaum muslimin yang di dalam Negara republik Indonesia ini merupakan mayoritas, oleh karenanya konsep pajak dunia modern dan konsep pajak dalam ekonomi Islam haruslah disingkronkan sehingga terwujud keharmonisan dalam bernegara dan memajukan kesejahteraan bangsa.

\section{TINJAUAN PUSTAKA}

Berdasarkan Undang-undang Nomor 28 Tahun 2007 pada pasal 1 (1), yaitu pengertian pajak adalah kontribusi wajib kepada negara yang terutang oleh orang pribadi atau badan yang bersifat memaksa berdasarkan undang-undang, dengan tidak mendapatkan imbalan secara langsung dan digunakan untuk keperluan negara bagi sebesar-besarnya kemakmuran rakyat. Menurut Rochmat Soemitro pajak adalah iuran rakyat kepada kas negara berdasarkan undang-undang (yang dapat dipaksakan) dengan tiada mendapat jasa imbalan (kontraprestasi), yang langsung dapat ditunjukkan dan yang digunakan untuk membayar pengeluaran umum /public investment (Soemarso, 2007).

Pajak adalah suatu pengalihan sumber-sumber yang wajib dilakukan dari sektor swasta kepada sektor pemerintah berdasarkan peraturan tanpa mendapat suatu imbalan kembali yang langsung dan seimbang. Penerimaan pajak dipergunakan pemerintah untuk melaksanakan tugas-tugasnya selama menjalankan pemerintahan (Kesit Bambang Prakosa, 2005). Dapat ditegaskan bahwa pajak adalah pungutan wajib yang dibayarkan oleh rakyat untuk negara dan akan digunakan untuk kepentingan pemerintah dan masyarakat umum. Rakyat yang membayar pajak tidak akan merasakan manfaat dari pajak secara langsung, karena pajak digunakan untuk kepentingan umum, bukan untuk 
kepentingan pribadi. Pajak merupakan salah satu sumber dana pemerintah untuk melakukan pembangunan, baik pemerintah pusat maupun pemerintah daerah. Pemungutan pajak dapat dipaksakan karena dilaksanakan berdasarkan undang-undang.

Berdasarkan pengertian diatas maka dapat disimpulkan bahwa pajak memiliki ciri-ciri, yaitu pajak merupakan kontribusi wajib warga negara, pajak bersifat memaksa untuk setiap warga negara, warga negara tidak mendapat imbalan langsung, berdasarkan undang-undang. Pajak memiliki peranan signifikan dalam kehidupan bernegara, khususnya pembangunan. Pajak merupakan sumber pendapatan negara dalam membiayai seluruh pengeluaran yang dibutuhkan, termasuk pengeluaran untuk pembangunan. Adapun fungsi pajak adalah sebagai anggaran (fungsi budgeter), pengatur (fungsi regulasi), pemerataan (pajak distribusi), dan stabilisasi.

Beberapa jenis pajak yang dipungut pemerintah dari masyarakat atau wajib pajak, yang dapat digolongkan berdasarkan sifat, instansi pemungut, objek pajak serta subjek pajak. Jenis pajak berdasarkan sifat, yaitu pajak tidak langsung (Indirect Tax) adalah pajak yang hanya diberikan kepada wajib pajak bila melakukan peristiwa atau perbuatan tertentu. Sehingga pajak tidak langsung tidak dapat dipungut secara berkala, tetapi hanya dapat dipungut bila terjadi peristiwa atau perbuatan tertentu yang menyebabkan kewajiban membayar pajak. Contohnya: pajak penjualan atas barang mewah. Pajak langsung (Direct Tax) adalah pajak yang diberikan secara berkala kepada wajib pajak berlandaskan surat ketetapan pajak yang dibuat kantor pajak. Di dalam surat ketetapan pajak terdapat jumlah pajak yang harus dibayar wajib pajak. Pajak langsung harus ditanggung seseorang yang terkena wajib pajak dan tidak dapat dialihkan kepada pihak yang lain. Contohnya: Pajak Bumi dan Penghasilan (PBB) dan pajak penghasilan.

Berdasarkan instansi pemungutnya, pajak digolongkan menjadi dua jenis, yaitu pajak daerah adalah pajak yang dipungut pemerintah daerah dan terbatas hanya pada rakyat daerah itu sendiri, baik yang dipungut Pemda Tingkat II maupun Pemda Tingkat I. Contohnya: pajak hotel, pajak hiburan, pajak restoran, dan masih banyak lainnya. Pajak negara (pusat) adalah pajak yang dipungut pemerintah pusat melalui instansi terkait, seperti: Dirjen Pajak, Dirjen Bea dan Cukai, maupun kantor inspeksi pajak yang tersebar di seluruh Indonesia. Contohnya: pajak pertambahan nilai, pajak penghasilan, pajak bumi dan bangunan, dan masih banyak lainnya. Berdasarkan objek dan subjeknya, pajak digolongkan menjadi dua jenis, yaitu: pajak objektif adalah pajak yang pengambilannya berdasarkan objeknya. Contohnya: pajak impor, pajak kendaraan bermotor, bea materai, bea masuk dan masih banyak lainnya. Pajak subjektif adalah pajak yang pengambilannya berdasarkan subjeknya. Contohnya: pajak kekayaan dan pajak penghasilan.

Seluruh pengadministrasian yang berhubungan dengan pajak pusat, dilaksanakan di Kantor Pelayanan Pajak (KPP), Kantor Pelayanan Penyuluhan 


\section{Islãmadîna \\ JURNAL PEMIKIRAN ISLAM}

dan Konsultasi Perpajakan (KP2KP), Kantor Wilayah Direktorat Jenderal Pajak serta Kantor Pusat Direktorat Jenderal Pajak. Sedangkan pengadministrasian yang berhubungan dengan pajak daerah, dilaksanakan di Kantor Dinas Pendapatan Daerah atau Kantor Pajak Daerah di bawah Pemerintah Daerah setempat.

Berdasarkan pendekatan hukum Islam (syariahh), istilah pajak terdiri dari kharaj (pajak bumi/tanaman), usyur (pajak perdagangan/bea cukai), dan jizyah (pajak jiwa terhadap non-muslim yang hidup di dalam naungan negara/pemerintahan Islam). Selain itu pajak dikenal juga dengan dengan nama

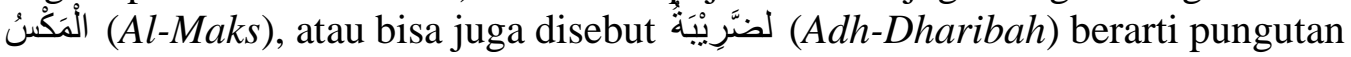
yang ditarik dari rakyat oleh para penarik pajak. Pajak dalam tinjauan bahasa arab adalah daribah, diambil dari kata daraba, berarti adalah utang yang mesti dibayar. Secara syari'ah pajak adalah kewajiban yang diterapkan terhadap wajib pajak yang harus disetorkan kepada negara sesuai dengan ketentuan, tanpa mendapatkan prestasi atau imbalan langsung dari negara (Hasanuddin, 2008). Istilah pajak dalam bahasa Arab lebih dikenal dengan nama adh-dharibah, yang artinya adalah beban. Ia disebut beban karena merupakan kewajiban tambahan atas harta setelah zakat, sehingga dalam pelaksanaannya akan dirasakan sebagai sebuah beban (Gazi Inayah, 2005).

Secara bahasa, dharibah dalam penggunaannya mempunyai banyak arti, namun para ulama memakai ungkapan dharibah untuk menyebut harta yang dipungut sebagai kewajiban dan menjadi salah satu sumber pendapatan negara. Kharaj adalah berbeda dengan dharibah, karena kharaj adalah pajak yang obyeknya adalah tanah (taklukan) dan subyeknya adalah non-muslim. Sementara jizyah obyeknya adalah jiwa (an-nafs) dan subyeknya adalah juga non-muslim (Gusfahmi, 2007). Pengertian pajak menurut pendapat Yusuf Qardhawi adalah kewajiban yang ditetapkan terhadap wajib pajak, yang harus disetorkan kepada negara sesuai dengan ketentuan, tanpa mendapat prestasi kembali dari negara dan hasilnya untuk membiayai pengeluaran-pengeluaran umum di satu pihak dan untuk merealisasi sebagian tujuan ekonomi, sosial, politik dan tujuan-tujuan yang ingin dicapai oleh negara. Abdul Qadim Zallum mengatakan bahwa pajak merupakan harta yang diwajibkan oleh Allah Swt kepada kaum muslim untuk membiayai berbagai kebutuhan dan pos-pos pengeluaran yang memang diwajibkan atas mereka, pada kondisi baitu mal tidak ada uang atau harta. (Zalum, 2002)

Berdasarkan pemaparan di atas, pajak dilihat sebagai kewajiban yang datang secara temporer, diwajibkan oleh alil amri (penguasa atau pemerintah) sebagai kewajiban tambahan sesudah zakat, karena kekosongan atau kekurangan harta atau kekayaan, dan juga dapat dihapus jika keadaan harta atau kekayaan sudah terisi kembali, diwajibkan hanya kepada kaum muslim yang kaya dan harus digunakan untuk kepentingan mereka (kaum Muslim), bukan kepentingan umum, dan ini sebagai bentuk jihad kaum muslim untuk mencegah datangnya bahaya yang lebih besar jika hal itu dilakukan. 
Unsur penting yang harus terdapat dalam ketentuan pajak menurut syariat Islam, yaitu diwajibkan oleh Allah Swt, objeknya adalah harta (al-mal), subjeknya kaum muslim yang kaya (ghaniyyun), tujuannya untuk membiayai kebutuhan mereka (kaum muslim) saja, diberlakukan karena adanya kondisi darurat (khusus), yang harus segera diatasi oleh ulil amri (Gusfahmi, 2007). Prinsip-prinsip penerimaan negara menurut sistem ekonomi Islam adalah harus adanya nash (Alquran dan Hadis) yang memerintahkan setiap sumber pendapatan dan pemungutannya, adanya pemisahan sumber penerimaan pajak dari kaum muslim dan non-muslim, sistem pemungutan pajak dan zakat haruslah menjamin bahwa hanya golongan makmur yang mempunyai kelebihan saja yang memikul beban utama, adanya tuntutan kepentingan umum (Gusfahmi, 2007).

\section{BERBAGAI PUNGUTAN HARTA PADA ZAMAN RASULULLAH}

Kota Yatsrib sebelum datangnya Islam tidak mempunyai pemimpin yang berdaulat. Kaum Aus dan Khazraj adalah dua kabilah terbesar di kota ini saling memperebutkan kekuasaan, sehingga beberapa kelompok dari mereka meminta Nabi Muhammad sawW menjadi pemimpin. Maka diadakanlah dua kali pertemuan yaitu tahun ke-12 kenabian yang dikenal Bai'at Aqabah pertama dan tahun ke-13 Kenabian yang dikenal sebagai Bai'at Aqabah kedua. Setelah Nabi Muhammad Saw hijrah nama Yatsrib kemudian berganti menjadi Madinah dan kemudian Nabi Muhammad Saw menjadi pemimpin bangsa di Kota Madinah. Ajaran Islam yang berkenaan dengan kehidupan masyarakat (muamalah) banyak turun di kota ini. (Adiwarman Azwar Karim, 2004).

Adapun yang telah dilakukan Nabi Muhammad Saw dalam kota Yatsrib ini, yaitu membangun Masjid Nabawi, merehabilitasi kaum Muhajirin melalui persaudaraan berdasarkan agama, menggantikan persaudaraan berdasarkan darah, menyusun konstitusi negara yang menyatakan kedaulatan Madinah sebagai sebuah negara berisi hak-kewajiban dan tanggung jawab setiap warga negara, stabilitas dan pertahanan negara. Adapun dalam bidang ekonomi khususnya Nabi Saw melakukan beberapa hal di kota Madinah, yaitu meletakkan dasar-dasar sistem keuangan negara berdasarkan syariah, mendirikan Baitul Mal yang bertugas semua hasil pengumpulan negara harus dikumpulkan terlebih dahulu dan kemudian dibelanjakan sesuai dengan kebutuhan negara, menetapkan kebijakan fiscal, yaitu langkah pemerintah untuk membuat perubahan-perubahan dalam sistem pajak atau dalam pembelanjaan (goverment expenditure). Tujuan kebijakan fiskal dalam perekonomian adalah tercapainya kesejahteraan sebagai adanya benefit maksimal bagi individu dalam kehidupan, terutama ditujukan untuk mencapai alokasi sumber daya secara efisien, stabilisasi ekonomi, pertumbuhan, dan distribusi pendapatan serta kepemilikan (Adiwarman Azwar Karim, 2004).

Kebijakan fiskal dan keuangan mendapat perhatian serius dalam perekonomian Islam sejak awal. Dalam negara Islam, kebijakan fiskal merupakan salah satu perangkat untuk mencapai tujuan syari'ah yang dijelaskan Imam Al-Ghazali termasuk meningkatkan kesejahteraan dengan tetap menjaga 


\section{Islãmadîna \\ JURNAL PEMIKIRAN ISLAM}

keimanan, kehidupan, intelektualitas, kekayaan, dan kepemilikan. Pada masa Rasulullah Saw hampir seluruh pekerjaan yang dikerjakan tidak mendapat upah, tidak ada tentara formal. Mereka tidak mendapatkan gaji tetap, namun diperbolehkan mendapat bagian dari rampasan perang, seperti senjata, kuda, unta dan barang- barang bergerak lainnya. Pada tahun kedua setelah hijrah, sedekah dan fitrah diwajibkan dan pembayarannya setiap bulan Ramadhan. Zakat mulai diwajibkan pembayaran pada tahun kesembilan hijrah.

Sumber penerimaan pada masa Rasulullah Saw, dapat digolongkan menjadi tiga golongan besar, yaitu dari kaum muslim, pendapatan kaum non-muslim dan sumber penerimaan yang lain. Penerimaan dari kaum muslim adalah kharaj (pajak tanah), zakat, ushr (bea impor), zakat fitrah, wakaf, infak dan shadaqah, amwal fadhal (harta benda kaum Muslimin yang meninggal tanpa ahli waris, atau berasal dari barang-barang seorang muslim yang meninggalkan negerinya), nawib (pajak yang jumlahnya cukup besar yang dibebani kaum muslimin dalam rangka menutupi pengeluaran negara selama masa darurat, ini pernah terjadi pada saat perang tabuk), khumus atas rikaz harta karun temuan pada periode sebelum islam

Pendapatan kaum non-muslim, yakni jizyah, kharaj, dan ushr. Sumber penerimaan yang lain, yakni ghanimah (harta rampasan perang), fay (harta dari daerah taklukan), uang tebusan untuk para tawanan perang, kaffarah atau denda, hadiah, dan pinjaman dari kaum muslimin dan non-muslim. Penerapan zakat, kharaj, dan jizyah juga mempunyai dasar yang sesuai dengan ajaran agama Islam, baik yang terdapat dalam Al Quran Hadits. Jadi, perintah membayark pajak tersebut merupakan tindakan religious menurut pandangan Islam (Mannan, 1997).

Dengan demikian jenis-jenis pungutan harta yang terdapat dalam fiqh Islam yang identik dengan konsep pajak negara modern, sebagai berikut. Zakat tidak hanya menciptakan pertumbuhan material dan spiritual bagi kelompok miskin, tetapi juga mengembangkan jiwa dan kekayaan kelompok kaya. Al Kasani menerangkan manfaat penting zakat adalah, pertama, menunaikan zakat merupakan upaya untuk menolong orang lemah dan memiliki keterbatasan, membantu orang yang mebutuhkan pertolongan, dan menompang mereka yang lemah agar mampu melaksanakan apa yang diwajibkan Allah swt. Kedua, membayar zakat dapat membersihkan diri pelakunya dari berbagai dosa dan menghaluskan budi pekertinya sehuingga menjadin orang yang pemurah dan mempunyai kepekaan sosial yang tinggi terhadap sesamanya, sehingga akan timbul rasa empati dan rasa solidaritas yang tinggi terhadap sesamanya. Ketiga, Allah swt telah melimpahkan rahmat dan karunia-Nya kepada kaum yang berkecukupan dengan memebrikan harta benda yang melebihi kebutuhan pokok, sehingga mereka harus mensyukuriatas kelebihan rezeki yang telah mereka terima.

Zakat dapat dirumuskan sebagai bagian dari harta yang wajib dibayarkan oleh setiap muslim beriman yang telah memenuhi syarat- syarat tertentu 
berdasarkan aturan dan tuntunan syariat, sebagai berikut, pertama, nisbah (jumlah minimum harta kekayaan yang wajib dikeluarkan zakatnya, setiap sumber memiliki kekayaan nisbah yang berbeda-beda, misalkan, antara harta perniagaan dan barang pertanian batas minimum harta yang wajib dikeluarkan adalah berbeda. Kedua, haul (jangka waktu yang ditentukan bila seorang wajib mengeluarkan zakat setiap sumber zakat memiliki batas waktu yang berbeda-beda, namum biasanya haul adalah satu tahun, kecuali produk pertanian haulnya adalah setiap panen dan tidak menunggu waktu satu tahun). Ketiga, kadarnya (ukuran besar zakat yang harus dikeluarkan, setiap zakat memiliki besaran yang berbeda).

Pada masa Rasulullah SAW zakat dikenakan pada hal-hal berikut, yaitu benda logam yang terbuat dari emas, seperti koin, perkakas, perhiasan atau dalam bentuk lainnya; benda logam yang terbuat dari perak seperti koin, perkakas, perhiasan atau dalam bentuk lainnya; binatang ternak, seperti unta, sapi, domba, dan kambing; berbagai jenis barang dagangan, termasuk budak dan hewan; hasil pertanian termasuk buah-buahan; luqathah, harta benda yang ditingalkan musuh; serta barang temuan (Adiwarman Azwar Karim, 2004)

Pungutan lain yang dikenal adalah jizyah, yaitu pajak yang dibayar oleh orang-orang nonmuslim sebagai pengganti fasilitas sosial ekonomi dan layanan kesejahteraan lainnya, serta untuk mendapatkan perlindungan keamanan dari negara Islam. Jizyah adalah pajak yang dipungut dari kaum non muslim karena berdomisili dan tunduk kepada pemerintah Islam. Besarnya tarif dipengaruhi oleh kemampuan material pembayar jizyah dan bisa dibayar individual atau kolektif. Meskipun jizyah merupakan hal yang wajib, namun dalam ajaran Islam ada ketentuan, bahwa wajib jizyah dikenakan kepada seluruh nonmuslim dewasa, laki-laki dan mampu membayarnya. Besarnya jizyah adalah satu dinar per tahun untuk setiap orang laki-laki dewasa yang mampu membayarnya. Hasil pembayaran jizyah akan dipergunakan untuk membiayai kepentingan kesejahteraan umum.

Sumber pajak lain pada masa awal Islam yaitu jizyah yang dipungut dari nonmuslim yang hidup dibawah pemerintahan Islam tetapi tidak mau masuk Islam. Pajak yang dikenakan pada mereka merupakan pengganti dari imbalan atas fasilitas ekonomi, pemerintahan Islam, juga sebagai jaminan dan keamanan hidup dan harta mereka. Pajak ini mirip dengan zakat fitrah yang dipungut dari muslim setiap tahun (Karim, 2014). Selain pungutan di atas masih ada pungutan lain, yaitu $u s h r$ adalah pajak bea impor yang dikenakan pada semua pedagang, dibayar hanya sekali dalam setahun dan hanya berlaku terhadap barang yang nilainya lebih dari 200 dirham. Rasulullah Saw berinisiatif mempercepat peningkatan perdagangan. Ushr dibebankan atas volume perdagangan, semakin besar volume perdagangan semakin besar pula ushr yang harus dibayarkan.

Besarnya tarif dipengaruhi oleh tarif yang dipungut oleh partner dagang, kemampuan bayar (minimal volume perdagangan 200 dirham), besarnya jasa yang diberikan pemerintah (tarif dzimmi lebih besar karena butuh jaminan 


\section{Islãmadîna \\ JURNAL PEMIKIRAN ISLAM}

keamanan lebih tinggi).

Sumber pendapatan yang pertama kali_diperkenalkan di zaman Rasulullah SAW adalah kharaj, yaitu pajak terhadap tanah. Kharaj ditentukan berdasarkan tingkat produktivitas dari tanah bukan zoning. Kharaj ini dibayarkan oleh seluruh anggota masyarakat baik orang-orang Muslim maupun nonmuslim. Penentuan jumlah besar pembayaran kharaj adalah pemerintah. Secara spesifik besarnya kharaj ditentukan berdasarkan karakteristik tanah atau tingkat kesuburan, jenis tanaman (termasuk tanaman yang memiliki nilai ekonomis dan kuantitas), jenis irigasi, metode produksi dan peran SDM yang lebih rendah, nilai hasil produksi (maksimal 50\%).

Kharaj merujuk pada pendapatan yang diperoleh dari biaya sewa atas tanah pertanian dan hutan milik umat Islam. Jika tanah yang diolah dan kebun buah-buahan yang dimiliki nonmuslim jatuh ketangan orang Islam akibat kalah dalam pertempuran, asset tersebut menjadi bagian dari harta milik umat Islam. Karena itu, siapapun yang ingin mengolah lahan tersebut harus membayar sewa. Pendapatan dari sewa inilah yang termasuk dalam lingkup kharaj. Contohnya adalah sewa yang dipungut atas beberapa lahan di Khaibar yang merupakan barang rampasan perang dan menjadi harta milik umat Islam.

Pungutan lain yang diperbolehkan dalam hukum Islam adalah ghanimah, yaitu jenis barang bergerak yang bisa dipindahkan, harta ini diperoleh dalam peperangan melawan musuh. Anggota pasukan akan mendapat bagian sebesar empat perlima dari jumlah yang ada dan sisanya dipergunakan bagi kepentingkan umum dan keluarga Nabi. Sementara itu, fai adalah harta benda yang diperoleh dari musuh tanpa harus melalui berperang atau berdamai. Biasanya dalam peperangan, sebelum terjadi penyerangan akan ditawarkan kepada musuh apakah bersedia menyerah atau tidak. Apabila mereka bersedia menyerah maka tidak akan diperangi, namun konsekuenasi dari ketaklukan tersebut adalah adanya harta benda yang diambil dari pihak musuh sebagai rampasan perang.

\section{PENERAPAN PUNGUTAN PAJAK DAN ZAKAT DI NEGARA REPUBLIK INDONESIA}

Perundang-undangan mengenai perpajakan yang berlaku di Indonesia saat ini adalah Undang-Undang Nomor 6 Tahun 1983 tentang Ketentuan Umum dan Tata Cara Perpajakan (UU Nomor 6 Tahun 1983) yang telah direvisi melalui Undang-Undang Nomor 9 Tahun 1994 tentang Perubahan Atas Undang-Undang Nomor 6 Tahun 1983 tentang Ketentuan Umum dan Tata Cara Perpajakan (UU Nomor 9 Tahun 1994). Besarnya perubahan perpajakan di masa ini, yaitu tahun 1983, dikenal sebagai tahun reformasi pajak. Sebelum diberlakukannya UU Nomor 6 Tahun 1983, sektor perpajakan di negara ini mengenal asas-asas pemungutan pajak yang disebut "Tri Dharma Perpajakan". Ketiga asas tersebut adalah sebagai berikut:

1. Bahwa pemungutan pajak harus adil dan merata yang meliputi subyek maupun obyek perpajakan. Sifatnya universal atau non diskriminatif. 
2. Harus ada kepastian hukum mengenai pemungutan pajak. Dengan kepastian hukum yaitu bahwa sebelum pemungutan pajak dilakukan harus ada undang-undang terlebihdahulu.

3. Ketepatan waktu pemungutan pajak. Membayar dan menagih harus tepat pada waktunya, aritinya pada saat orang memiliki uang (asas conveniency dan efisiensi).(Ashar, 2013)

Penerimaan suatu daulah Islam memang terbesar berasal dari zakat dan pajak, hal ini bisa dilihat dari sejarah peradaban muslim. Karena itu, pajak dan zakat selalu menjadi pembahasan yang terintegrasi, khususnya bagi negara mayoritas muslim seperti Indonesia. Meskipun terdapat perbedaan pendapat pro dan kontra tentang pajak, yaitu ada yang berpendapat bahwa pajak adalah haram karena mengambil harta orang secara batil, yang dibolehkan hnya zakat saja. Namun demikian, ada juga yang berpendapat zakat dan pajak bisa berdampingan dalam sebuah negara yang dihuni kaum muslimin seperti Indonesia. Kelompok lain mengambil jalan tengah antara keduanya, yaitu bagi yang sudah membayar zakat tertentu berarti sudah membayar pajak.

Umat Islam di Indonesia yang sudah membayar zakat memang terkena pengeluaran berganda, selain membayar pajak juga membayar zakat dari penghasilan yang diperolehnya. Pada tanggal 23 Agustus 2010, pemerintah sudah menerbitkan Peraturan Pemerintah No. 60 tahun 2010 yang berisi bahwa zakat dan atau sumbangan keagamaan lain yang bersifat wajib dapat dikurangkan dari penghasilan bruto. Sampai saat ini masalah tersebut masih terjadi perdebatan di kalangan ahli hukum Islam Indonesia mengenai persamaan pembayaran pajak sebagai pembayaran zakat.

Dalam kaitan masalah pajak dan zakat di Negara Indonesia ini, Syauqi Ismail Sahata dalam buku Penerapan Zakat dalam Dunia Modern membahas boleh tidaknya memungut pajak di samping zakat. Penulis menunjuk pendapat Muhammad Abu Zahrah yang menyanggah pendapat sebagian ulama bahwa pajak-pajak yang berlaku di negara-negara Islam adalah berfungsi sebagai zakat. Pendapat seperti itu menurutnya tidak sesuai dengan tujuan hakiki disyariatkannya zakat dalam Islam. Kewajiban zakat adalah untuk menanggulangi kemiskinan, membantu orang-orang fakir dan memenuhi kebutuhan kaum melarat, dan juga untuk membiayai kelancaran dakwah Islam, dimana hal itu tidak termasuk bidang-bidang yang dibiayai dengan pajak. Sekalipun ada sedikit pembelanjaan pajak untuk kaum dhuafa, tetapi sifatnya sekunder dan bukan tujuan utama.

Pemungutan pajak di samping zakat adalah boleh, sesuai dengan prinsip al-mashalihul mursalah. Jika belakangan ini muncul gagasan untuk memperjuangkan zakat sebagai pengurang pajak (tax credit), tentu hal itu memerlukan pemikiran dan koordinasi yang baik dan tepat dalam merealisasikannya. Kalau pun sekarang belum terwujud, siapa tahu suatu saat 


\section{Islãmadîna \\ JURNAL PEMIKIRAN ISLAM}

nanti menjadi kenyataan. Gagasan yang sulit untuk diterima adalah menyamakan zakat dengan pajak. (Nasar, 2014)

Ulama dalam menyikapi penerapan dan integrasi zakat dan pajak seperti yang ada di Indonesia ini secara umum terbagi menjadi tiga pendapat, yaitu pertama, adalah yang berpendapat bahwa zakat adalah tidak sama dengan pajak, zakat adalah kewajiban agama dan pajak adalah kewajiban terhadap negara. Oleh karenanya masing masing harus ditunaikan. pendapat pertama, dimotori oleh Syekh Yusuf Qardawi yang berpendapat bahwa zakat adalah kewajiban agama berdiri sendiri dan pajak adalah kewajiban terhadap negara yang juga berdiri sendiri. Kedua, pajak tidaklah wajib, bahkan hukumnya haram dikenakan kepada kaum muslimin, hal ini disandarkan kepada dalil misalnya hadits riwayat Bukhari dan Muslim, "Apakah ada kewajiban lain di luar zakat? Nabi menjawab, ”Tidak ada, kecuali shadaqah sunnah". (HR Bukhari dan Muslim). Pendapat Kedua dimotori oleh Hasan Turobi, dari negeri Sudan dengan pendapatnya bahwa pajak tidak boleh bahkan haram dilakukan karena bentuk kazaliman. Pendapat yang ketiga, adalah pendapat yang menyamakan pajak dengan zakat yaitu orang yang telah membayar pajak berarti juga telah membayar zakat, ini pendapat Masdar F. Masudi, menurutnya zakat adalah roh dan pajak adalah badannya. (Masdar Farid Mas'udi, 2002). Menurut Masjfuk Zuhdi, tidak perlunya membayar zakat jika sudah membayar pajak didasarkan pada dalil istishab dan kaidah hukum ushul fiqh al aslu baqaun makana ala makana. (Masjfuk Zuhdi, 1987)

Apabila subyek zakat adalah orang-orang muslim yang memiliki harta kekayaan yang cukup senishab, yang disebut dengan istilah muzakky, maka subyek pajak di Indonesia sudah ditetapkan dalam undang-undang RI nomor 7 Tahun 1983, Bab II Pasal 2, ayat 1 dan 2 berbunyi yang menjadi subyek pajak adalah orang pribadi atau perorangan warisan yang belum terbagi sebagai kesatuan menggantikan yang berhak, badan yang terdiri dari perseroan terbatas, petseroan komanditer, badan usaha milik negara dan daerah dengan atas nama dan dalam bentuk apapun, persekutuan perorangan atau perkumpulan lainnya, firma, kongsi, perkumpulan koperasi, yayasan atau lembaga dan bentuk usaha tetap. Subyek pajak terdiri dari pajak dalam negeri dan pajak luar negeri yaitu subyek pajak yang tidak bertempat tinggal, tidak didirikan, atau tidak berkedudukan di Indonesia, yang dapat menerima atau memperoleh penghasilan dari Indonesia.

Subyek pajak yang ditentukan sejak awal perkembangan Islam adalah meliputi orang-orang muslim, Ahlu Dzimmi dan Ahlu Harbi, berbeda jenis dan ketentuannya masing masing yang sangat jauh berbeda dengan subyek pajak menurut ketentuan perpajakan yang telah diundangkan oleh pemerintah Indonesia, akan tetapi menurut satu pendapat pajak ini tidak bertentangan dengan hukum Islam, karena pajak yang telah dikumpulkan dari wajib pajak, digunakan untuk meningkatkan kesejahteraan penduduk yang sebenarnya suatu hal yang menjadi salah satu sasaran ajaran Islam. Meskipun pajak dan zakat 
memiliki titik singgung yang sama, yaitu kewajiban yang mengikat, dan kekuasaan yang menekan, namun di antara keduanya terdapat perbedaan penting, yaitu:

1. Bahwa zakat itu adalah ibadah, dan pajak adalah kewajiban kepada negara. Pajak berhubungan antara warga dan negara. zakat adalah hubungan manusia dengan Tuhannya. Seorang muzakki akan membayar zakatnya, meskipun tidak ada yang menagihnya.

2. Dari aspek kewajiban. Zakat hanya diwajibkan bagi umat Islam, sedangkan umat yang beragama lain tidak terkena kewajiban zakat. Sedangkan pajak, wajib bagi setiap warganegara, baik yang beragama Islam maupun lainnya.

3. Subyek zakat adalah orang kaya. Hal ini dibuktikan bahwa yang harus membayar zakat adalah orang yang hartanya telah mencapai nishab. Sedangkan pajak tidak pandang bulu, semua warga negara baik kaya maupun miskin harus bayar pajak.

4. Zakat hanya diperuntukkan bagi delapan golongan mustahik, yaitu fakir, miskin, amil zakat, muallaf, riqob, gharimin, ibnu sabil, dan fi sabilillah (QS. At-Taubah: 60). Adapun peruntukan pajak adalah sangat tergantung situasi dan kondisi negara pada saat itu. Suatu saat digunakan untuk membangun infrastruktur, lain waktu untuk program pendidikan, atau untuk membayar pokok dan bunga pinjaman.

5. Zakat harus disalurkan secara langsung kepada yang berhak (yaitu delapan asnaf mustahik), tidak boleh ditahan-tahan terlalu lama. Sedangkan pajak, secara konsep dan praktek, pemanfaatannya adalah secara tidak langsung. Jadi pembayar pajak tidak bisa menuntut pemerintah untuk segera menggunakannya untuk kepentingan rakyat, tetapi tergantung pada mekanisme yang ada di pemerintahan (pemerintah dan DPR).

6. Tarif zakat sudah baku, tidak bisa diubah-ubah. Sedangkan tarif pajak bisa diubah disesuaikan dengan kondisi.

7. Zakat ada nishabnya, sedangkan pajak tidak ada ketentuan yang jelas kecuali ditentukan oleh penguasa di suatu tempat.

8. Zakat adalah salah satu bentuk sunnah yang dicontohkan oleh Rasulullah SAW Sedangkan pajak asal-usulnya pungutan oleh para raja Arab atau non Arab, dan diantara kebiasaan mereka ialah menarik pajak sepersepuluh dari barang dagangan manusia yang melalui/melewati daerah kekuasannya.

9. Pajak terbatas sasarannya, hanya pada target materi sedangkan zakat memiliki sasaran Ruhiyah, akhlak, dan insaniyah (kemanusiaan). Zakat adalah ibadah yang sekaligus pungutan.(Mahjuddin, 2008)

Ada lima alasan yang membolehkan kewajiban pajak selain pembayaran zakat yang harus di laksanakan kaum muslim di Indonesia, sebagai berikut: 


\section{Islãmadîna \\ JURNAL PEMIKIRAN ISLAM}

1. Jaminan/solidaritas sosial merupakan suatu kewajiban. Pajak merupakan sumber pembiayaan bagi kebutuhan sosial oleh karena itu, apabila dana zakat tidak mencukupi untuk pemenuhan kebutuhan sosial tersebut maka dibolehkan adanya pungutan-pungutan diluar zakat seperti pajak.

2. Sasaran zakat itu terbatas, sedangkan pembiayaan banyak sekali. Zakat harus di gunakan pada sasaran yang di tentukan oleh syariah dan menempati fungsinya yang utama dalam menegakkan solidaritas sosial, atas dasar itu ulama berpendapat bahwa zakat tidak boleh dipergunakan untuk membangun jembatan, perbaikan jalan dan yang lainnya. Maka untuk membiayai kepentingan umum dibolehkan adanya ketentuan pajak bagi kaum muslim.

3. Kaidah-kaidah hukum syara'. Dengan menggunakan kaidah yang berlandaskan nash (yaitu Al-Qur'an dan Sunnah), pajak bukan hanya dibolehkan, tetapi juga diwajibkan pemungutannya untuk merealisasikan kepentingan umat dan negara, apabila sumber penerimaan lain tidak mencukupi.

4. Jihad atas harta dan tuntutannya yang besar. Islam mewajibkan kepada umatnya untuk berjihad di jalan Allah dengan harta jiwa. Salah satu bentuk jihad dengan harta yang diperintahkan adalah kewajiban lain di luar zakat.

5. Kerugian dibalas dengan keuntungan. Dana yang diperoleh dari pajak dipergunakan untuk membiayai segala keperluan negara yang manfaatnya kembali kepada seluruh rakyat. (Nuruddin Mhd Ali, 2006)

Oleh karena itu, pelaksanaan dan penerapan konsep pajak dan zakat di Indonesia ini bagi masyarakat muslim agar sesuai dengan konsep pemikiran ekonomi Islam dapatlah memilih apakah ia akan membayar pajak sebagai kewajiban negara dan juga membaya zakat sebagai kewajiban agama, ataupun dia menganggap sama bahwa ia membayar pajak sebagai bagian daripada zakatnya. Sebaiknya memang bisa dilaksanakan keduanya antara pungutan zakat dan pajak secara integrasi di Negara Indonesia yang mayoritas penduduknya beragama Islam ini. Adapun yang dilarang bagi warga muslim di Indonesia adalah ia tidak membayar pajak, karena Indonesia bukanlah daulah Islamiyah yang menyatukan antara pembayaran zakat dan pajak, maka yang tidak membayar zakat juga tidak dapat dikenakan sanksi hukum. Dalam Ekonomi Islam yang menjadi acuan adalah kehidupan akherat dan ridha Allah Swt. Semua adalah alat untuk mengabdi kepada Rabul alamin, termasuk pajak dan zakat, selain dilihat secara materialnya atau harta benda yang dapat memberikan kepuasan hidup di dunia, akan tetapi zakat dan pajak juga harus beroreintasi kepada ridha Allah dan akherat kelak.

Mengenai proses regulasi pengelolaan zakat sehingga zakat dapat mengurangi pembayaran pajak (pajak penghasilan), hal ini sudah diatur sejak adanya UU No. 38 Tahun 1999 tentang Pengelolaan Zakat, dan kemudian lebih dipertegas oleh UU Zakat yang terbaru yang menggantikan UU 38/1999 yaitu UU No. 23 Tahun 2011 tentang Pengelolaan Zakat. Latar belakang dari 
pengurangan ini dijelaskan dalam penjelasan Pasal 14 ayat (3) UU 38/1999 bahwa pengurangan zakat dari laba/pendapatan sisa kena pajak adalah dimaksudkan agar wajib pajak tidak terkena beban ganda, yakni kewajiban membayar zakat dan pajak. Ketentuan ini masih diatur dalam UU yang terbaru yakni dalam Pasal 22 UU 23/2011 berbunyi Zakat yang dibayarkan oleh muzaki kepada BAZNAS atau LAZ dikurangkan dari penghasilan kena pajak.

Hal ini ditegaskan pula dalam ketentuan perpajakan sejak adanya UU No. 17 Tahun 2000 tentang Perubahan Ketiga atas UU No. 7 Tahun 1983 tentang Pajak Penghasilan, yakni diatur dalam Pasal 4 ayat (3) huruf a nomor 1, berbunyi bahwa yang tidak termasuk sebagai Objek Pajak adalah: bantuan sumbangan, termasuk zakat yang diterima oleh badan amil zakat atau lembaga amil zakat yang dibentuk atau disahkan oleh Pemerintah dan para penerima zakat yang berhak. Sedangkan badan/lembaga yang ditetapkan sebagai penerima zakat atau sumbangan keagamaan yang sifatnya wajib yang dapat dikurangkan dari penghasilan bruto diatur dalam Peraturan Direktur Jenderal Pajak No. PER-15/PJ/2012 yang berlaku sejak tanggal 11 Juni 2012 yang sebelumnya diatur dengan Peraturan Direktur Jenderal Pajak No. PER- 33/ PJ/2011, yang diantaranya adalah: Badan Amil Zakat Nasional, LAZ Dompet Dhuafa Republika, LAZ Yayasan Rumah Zakat Indonesia, Lembaga Sumbangan Agama Kristen Indonesia (LEMSAKTI), dan Badan Dharma Dana Nasional Yayasan Adikara Dharma Parisad (BDDN YADP) yang keseluruhannya saat ini berjumlah 21 badan/lembaga.(Wahid, 2016)

Salah satu solusi dan rekomendasi atas sistem pungutan pajak dan zakat di Indonesia agar sesuai dengan sistem ekonomi Islam yang saling terintegrasi pada saat ini antara lain adalah perlunya dibentuk badan atau pihak yang bertanggung jawab atas masalah zakat dan pajak. Dalam kitab Shahih Bukhari yang diriwayatkan dari sahabat Ibnu Abbas sebagaimana dikutip oleh Yusuf Al Qardhawi yang menjelaskan mengenai pihak yang bertanggung jawab atas pungutan zakat di negara adalah pemerintah. Tanggung jawab pemerintah dalam pemungutan zakat terdiri dari :

1. Pembuatan aturan mengenai pemungutan zakat

2. Melakukan pengawasan terhadap zakat yang dibayar oleh masyarakat,

3. Melakukan penegakan hukum terhadap orang yang enggan membayar zakat dan membayar zakat dengan jumlah yang kurang dari seharusnya, dan melakukan pengelolaan dana zakat dan mendistribusikannya kepada pihak yang berhak menerima. (Ramadhan, 2017)

Pemerintah sebagai pihak yang bertanggung jawab terhadap pemungutan dan pengelolaan dana zakat harus menentukan perwakilan pemerintah yang bertanggung jawab terhadap pemungutan zakat dan administrasi serta pengawasan wajib zakat. Indonesia saat ini mengandalkan BAZNAS dan LAZ sebagai pemungut dana zakat, pengelola, serta pendistribusi dana zakat dan sebagaimana yang telah penulis sebutkan di 


\section{Islãmadîna \\ JURNAL PEMIKIRAN ISLAM}

bagian pendahuluan, penerimaan zakat hanya mencapai $23,13 \%$ dari potensi yang seharusnya dapat dipungut. Maka dari itu, perlu adanya suatu lembaga khusus yang hanya bertugas untuk pemungutan zakat dan administrasi zakat yang terpisah dari pendistribusi dana zakat dengan kriteria sebagai berikut:

1. Lembaga tersebut berada di bawah Kementerian Keuangan. Lembaga tersebut harus berada dibawah kementerian keuangan sebagai bentuk adanya integrasi fiskal antara pajak dengan zakat. Kementerian Keuangan selaku penanggungjawab kebijakan fiskal akan lebih mudah mengatur kebijakan yang akan diambil apabila lembaga pemungutan zakat berada di bawah Kementerian Keuangan.

2. Lembaga tersebut dapat disatukan dengan Direktorat Jenderal Pajak. Mengingat adanya kesamaan fungsi antara zakat dengan pajak, lembaga pemungut zakat dan pajak dapat disatukan dalam satu organisasi karena hal ini tentunya lebih efisien dibandingkan dengan membentuk suatu lembaga baru yang khusus menjalankan pemungutan pajak.

3. Selain itu, dengan sebaran Kantor Pelayanan Pajak yang berada di seluruh Indonesia, akan lebih mengefektifkan pemungutan zakat apabila di dalam Kantor Pelayanan Pajak ditambahkan fungsi baru. Apabila lembaga pemungut zakat digabungkan ke dalam Direktorat Jenderal Pajak perlu ditambahkan beberapa unit organisasi baru di dalam Direktorat Jenderal Pajak, diantaranya:

a. Membentuk suatu sub direktorat di Direktorat Peraturan Perpajakan I/II yang memiliki fungsi untuk membuat regulasi terkait pemungutan zakat

b. Membentuk suatu sub direktorat di Direktorat Potensi, Kepatuhan, dan Peneimaan yang memiliki fungsi membuat kebijakan terkait penggalian potensi di bidang zakat.

c. Menambahkan fungsi di sub direktorat penilaian sebagai penilai harta zakat

d. Membentu suatu bidang baru disetiap Kanwil DJP yang bertugas untuk melakukan penggalian potensi zakat di wilayahnya masing-masing.

e. Membentuk suatu seksi baru di Kantor Pelayanan Pajak yang bertugas untuk melakukan pengawasan atas zakat yang dibayar.

Selain lembaga pemungutan, perlu juga dipikirkan mengenai lembaga yang bertugas mengelola dana zakat dan mendistribusikan zakat kepada pihak yang berhak menerimanya. Saat ini, yang bertugas dalam pengelolaan dan pendistribusian kas negara adalah Direktorat Jenderal Perbendaharaan Negara (DJPB). Guna efisiensi, pemerintah tidak perlu membuat lembaga baru untuk pengelolaan dan pendistribusian zakat, akan tetapi dapat menggabungkan fungsi pengelolaan dana zakat di 
DJPB. (Ramadhan, 2017). Untuk lebih memikat muzakki, memang mestinya zakat yang semula hanya sebagai pengurang penghasilan kena pajak (PPKP) ditingkatkan menjadi pengurang pajak (tax deductible). Dengan demikian, fungsi zakat sebagai penghargaan (reward) terhadap pembayar pajak, menjadi lebih signifikan. Dengan kebijakan itu, meski pajak secara prosentase menjadi lebih kecil namun proyeksi total amount-nya akan lebih besar seiring besarnya semangat rakyat membayar pajak (Ashar, 2013). Program ini kemudian sebaiknya dilanjutkan dengan pembentukan kolaborasi antara BAZNAS dan Direktorat Perpajakan.

Dalam perkembangannya ke depan, pola sinergitas pajak dan zakat diharapkan bukan hanya tertuang dalam perundang undangan tetapi perlu skema lain yang aplikatif, misalnya ada kolaborasi program BAZNAS seagai badan resmi zakat nasional dan pemerintah melalui direktorat perpajakan. Program program penyuluhan, promosi, informasi di media misalnya, kolaborasi BAZNAS dan Direktorat Perpajakan dalam meningkatkan target penerimaan zakat atau pajak mesti dilakukan. Dengan demikian manfaat peningkatan penerimaan zakat dan pajak tersebut dapat maksimal sehingga berdampak positif bagi program pengentasan kemiskinan.

Di Indonesia, zakat dan pajak belum berkolaborasi menjadi satu. Pengelolaan zakat dan pajak masih terpisah berdiri masing masing. Zakat dipegang oleh amil zakat dan pajak dikelola oleh pemerintah. Hanya saja, perhitungan zakat sudah dimasukan untuk menjadi kredit pajak dalam Surat Pemberitahuan Tahunan. Haparan ke depannya, dengan melakukan pembenahan yang sistematis, Indonesia dinilai akan mampu melampaui negara mayoritas muslim lainnya dalam hal penerimaan zakat maupun pajak. (Afriyandi, 2014)

\section{SIMPULAN}

Al Quran merupakan sumber utama ajaran Islam sudah menetapkan berbagai aturan sebagai hidayah (petunjuk) bagi umat manusia dalam melakukan aktifitas disetiap aspek kehidupannya, termasuk bidang ekonomi. Pajak adalah pungutan wajib yang dibayar rakyat untuk negara dan akan digunakan untuk kepentingan pemerintah dan masyarakat umum. Rakyat yang membayar pajak tidak akan merasakan manfaat dari pajak secara langsung, karena pajak digunakan untuk kepentingan umum, bukan untuk kepentingan pribadi. Pajak merupakan salah satu sumber dana pemerintah untuk melakukan pembangunan, baik pemerintah pusat maupun pemerintah daerah. Selain pajak pungutan harta al-dharibah dan al-maks dalam konsep fiqh Islam ada beberapa jenis pugutan yang indentik dengan pajak, antara lain seperti zakat, kharaj, usyr, jizyah, ghanimah dan fai. Jenis pungutan ini berbeda praktek pelaksaannnya karena telah diatur oleh agama dan tidak boleh dirubah oleh siapapun.

Pemerintah Indonesia sebagai pihak yang bertanggung jawab terhadap 


\section{Islãmadîna \\ JURNAL PEMIKIRAN ISLAM}

kesejahteraaan rakyat wajib mengelola pungutan dan pengelolaan dana pajak dan zakat secara profesional, amanah, dan modern. Diantaranya dengan membentuk lembaga perwakilan pemerintah yang bertanggung jawab terhadap pungutan pajak dan zakat serta pengawasan managerial keduanya seperti Badan Amil Zakat Nasional dan direktorat pajak, yang kemudian membentuk kerjasama antara Badan Amil Zakat tingkat Nasional dan direktorat pajak yang kolaboratif agar terjalin sinergitas antara pungutan zakat dan pajak, dalam pemungutan dana, pengelolaan, pendistribusi dan aplikasi program peningkatan pendapatan pajak dan zakat serta kemajuan ekonomi bangsa sesuai dengan syariat Islam dan perundang-undangan pemerintah Republik Indonesia.

\section{DAFTAR PUSTAKA}

Adiwarman Azwar Karim. (2004). Sejarah Pemikiran Ekonomi Islam. Jakarta: PT RajaGrafindo Persada.

Afriyandi, Y. (2014). sinergitas Pajak dan Zakat Dalam Keuangan Publik Islam. Rasail, 2(1), 279.

Ashar. (2013). Pajak Dan Zakat: Suatu Kajian Komparatif. Fenomena, V(2).

Gazi Inayah. (2005). Teori Komprehensif Tentang Zakat dan Pajak. Yogyakarta: Tiara Wacana.

Gusfahmi. (2007). Pajak Menurut Syariah. Jakarta: PT. Raja Grafindo Persada.

Hasanuddin, H. N. dan M. (2008). Ensiklopedi Ekonomi dan Perbankan Syari'ah. Bandung: Kafa Publishing.

Karim, A. (2014). Ekonomi Makro Islam. Jakarta: Rajawali Pers.

Kesit Bambang Prakosa. (2005). Hukum Pajak. Yogyakarta.: EKONISIA.

Mahjuddin. (2008). Masailul Fiqhiyah. Jakarta: Kalam Media.

Mannan, M. . (1997). Islamic Economic, Theory and Practice. Yogyakarta: PT. Dana bhakti Wakaf.

Masdar Farid Mas'udi. (2002). Agama Keadilan; Risalah Zakat (Pajak) Dalam Islam. Jakarta: P3M.

Masjfuk Zuhdi. (1987). Pengantar Hukum Syariah. Jakarta: Haji mas Agung.

Nasar, M. F. (2014). Pengembangan dan Implementasi zakat wakaf, 1-3.

Nuruddin Mhd Ali. (2006). Zakat Sebagai Intrumen Dalam Kebijakkan Fiscal. Jakarta: PT Raja Grafindo Persada.

Ramadhan, M. R. (2017). Integrasi Pajak Dan Zakat Di Indonesia. Islamiconomic: Jurnal Ekonomi Islam, 8, 77-94.

Soemarso. (2007). Perpajakan Pendekatan Komprehensif. Jakarta: Salemba Empat. 
Wahid, M. A. R. (2016). Integrasi Pajak Dan Zakat Di Indonesia Perspektif Hukum Islam Dan Hukum Positif. El-Jizya, 4(1), 27-58.

Zalum, A. Q. (2002). Sistem Keuangan di Negara Khilafah. Bogor: Pustaka Thariq al-Izzah,.

http://www.pajak.go.id/content/buku-peraturan-perpajakan

https://lailynurarifa.wordpress.com/2012/12/12/zakat-dan-pajak-dalam-islam

https://almanhaj.or.id/2437-pajak-dalam-islam

https://baznas.go.id 